\title{
Oxygen-Induced Retinopathy: Lack of Adverse Heparin Effect
}

\author{
ROSEMARY D. HIGGINS AND DALE L. PHELPS \\ University of Rochester Medical Center, Departments of Pediatrics and Ophthalmology, \\ Rochester, New York 14642
}

\begin{abstract}
Retinopathy of prematurity is a disorder of abnormal retinal vascular proliferation, and one hypothesis for its pathogenesis involves abnormal activity of angiogenic growth factors in the retina. One of these, acidic fibroblast growth factor, is found primarily in retina and brain tissues. Its mitogenic effect is greatly potentiated in vitro by heparin. Because retinopathy of prematurity occurs most often in premature infants who receive the greatest amount of heparin, we tested the hypothesis that heparin may adversely affect the retinopathy observed in kittens after hyperoxic ( $80 \%$ oxygen) exposure. Seventeen litters of kittens were randomly assigned to receive either saline or heparin s.c. injections from $d 2$ through recovery to $28 \mathrm{~d}$ of age; $65 \mathrm{~h}$ of high oxygen exposure was started on $\mathrm{d} 3$ to induce a standard retinal injury in our model. There were no differences in the degree of retinopathy between the heparin-treated group [severity score $5.9 \pm$ 2.2 (mean $\pm \mathrm{SD}$ )], and the saline-treated group (severity score $7.1 \pm 1.7, p>0.20,80 \%$ power to detect a 2 -point difference in score at $\alpha=0.05$ ). These findings do not support a concern that clinical doses of heparin potentiate retinopathy of prematurity. (Pediatr Res 27: 580-582, 1990)
\end{abstract}

\section{Abbreviations}

OIR, oxygen-induced retinopathy

ROP, retinopathy of prematurity

FGF, fibroblast growth factor

aFGF, acidic fibroblast growth factor

bFGF, basic fibroblast growth factor

ROP is a vasoproliferative disorder of immature retinal vessels initially described in 1942 (1) and subsequently found to be increased in frequency by prolonged routine supplemental oxygen (2-6). Animal models of a similar retinopathy have been described $(7,8)$. Despite the early restriction of oxygen use $(6)$ and subsequent strict monitoring of blood oxygen $(9,10)$, the problem of ROP persists, albeit at a lower frequency, and the complete pathophysiology remains unclear.

Gestational age correlates with the degree of retinal vessel maturity and is the major risk factor for the development of ROP (10-12). Case-matched studies controlled for gestational age show that the sickest infants are at greatest risk for ROP (11, 12). These infants have multiple procedures including i.v. cannulations in greater numbers for longer periods of time. This is associated with the long-term need for i.v. access and heparin to

Received November 14, 1989; accepted January 17, 1990.

Correspondence: Rosemary D. Higgins, M.D., University of Rochester School of Medicine and Dentistry, Box 651, Departments of Pediatrics (Neonatology) and Ophthalmology Rochester, NY 14642.

Funded in part by USPHD, NIH, and National Eye Institute Grant EY06068 preserve these lines (13). Therefore, the sickest infants are exposed to more heparin for longer periods of time, and these are the infants at highest risk for ROP.

ROP results when aberrant retinal vessel regrowth occurs after an initial injury. It has been thought to be driven by ischemic avascular tissue releasing angiogenic growth factors as has recently been demonstrated in the kitten model of OIR (14). Presumably, the angiogenic growth factors, initially called retinalderived growth factors and later found to be largely aFGF and bFGF (15), are contributing to the development of ROP. Observations in infants and experimental animals suggest that retinal ischemia is positively correlated with angiogenesis in OIR (16) and other retinopathies as well (17). The retinopathies develop in unregulated pathologic manners, possibly because of excessive signals for capillary growth.

Capillary growth and development has been demonstrated to be influenced by several growth factors $(18,19)$. Acidic FGF, found mainly in neural tissue, is relatively abundant in the retina (15), and is mitogenic for a variety of cell types including endothelial cells (20). Significantly, many of the effects of aFGF in vitro are potentiated by heparin or heparin-like molecules (21$23)$. Acidic FGF activity is potentiated by heparin in vitro (24, $25)$; the importance of size, sulfation, and anticoagulant activity has been described (26). Furthermore, heparin copper-complex has been shown to be angiogenic in vivo (27). Basic FGF is also angiogenic, and has been shown to positively influence capillary growth in vitro but has not been shown to be potentiated by heparin. Other unknown factors may also contribute to abnormal vessel growth in ROP.

A logical concern is that widespread heparin use for maintaining central lines and for use in hyperalimentation might exacerbate ROP by potentiating aFGF in vivo. We therefore undertook a study to test the hypothesis that heparin may adversely affect OIR in the kitten model of OIR.

\section{MATERIALS AND METHODS}

Seventeen pathogen-free pregnant queens were obtained from a commercial vendor (Liberty Laboratories, Liberty Corner, NJ). The day that kittens were first observed was defined as $\mathrm{d} 1$. Within each litter, the kittens were randomly assigned to receive heparin $(150 \mathrm{U} / \mathrm{kg} / \mathrm{d})$ or saline (equal volume) s.c. divided every $12 \mathrm{~h}$ beginning on $\mathrm{d} 2$ (both solutions with benzyl alcohol as a preservative). On d 3, the queen and her kittens were placed in an infant incubator (Air Shields Isolette, Hatboro, PA) at $26^{\circ} \mathrm{C}$ with oxygen concentration adjusted to $80 \pm 1 \%$ for a total $65 \mathrm{~h}$ to produce a standard OIR $(16,28-30)$. The study design is depicted in Figure 1. Oxygen concentrations were measured at least twice daily with a Beckman oxygen analyzer (Beckman Instruments, Inc., Fullerton, CA) and were consistently stable. Kittens subsequently recovered in room air, continuing to receive either heparin $(n=28)$ or saline $(n=32)$ injections until $28 \pm 2$ d of age (Fig. 1). The dose of heparin (Heparin lock flush solution, USP, $10 \mathrm{U} / \mathrm{mL}$, Elkins-Sinn, Inc., Cherry Hill, NJ) was based 


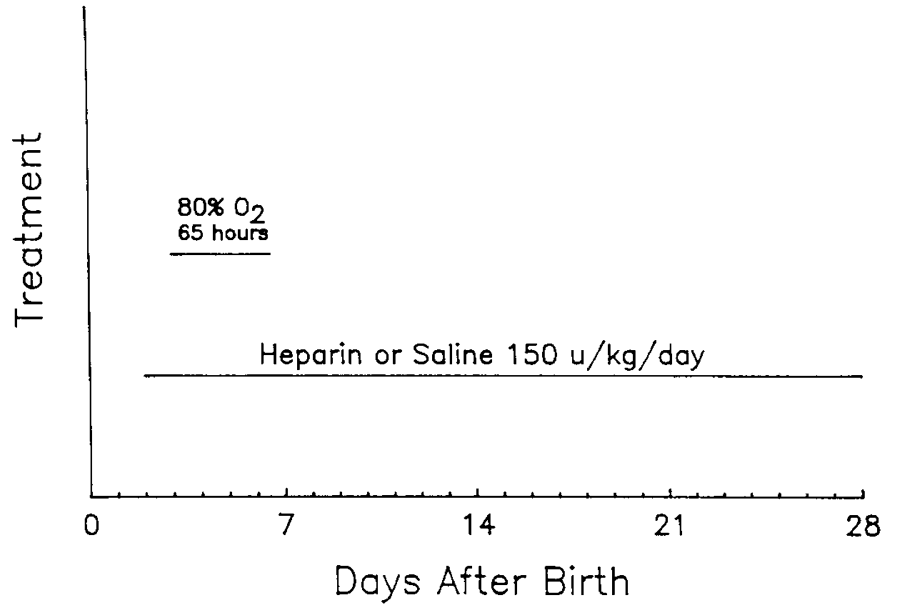

Fig. 1. Experimental design. Time in days on the $x$-axis and various therapies (oxygen exposure, heparin, saline) on the $y$-axis of the experimental design.

\begin{tabular}{|c|c|c|c|c|c|}
\hline $\begin{array}{c}\text { SCORE } \\
\text { CATEGORY }\end{array}$ & 0 & 1 & 2 & 3 & 4 \\
\hline $\begin{array}{l}\text { VESSEL } \\
\text { GROWTH } \\
\text { A }\end{array}$ & $\begin{array}{l}\text { EOUAL TO } \\
\text { CONTROL. }\end{array}$ & $\begin{array}{l}\text { MILDLY RETARDED } \\
\text { ESPECIALLY } \\
\text { TEMPORALLY }\end{array}$ & $\begin{array}{l}\text { RETARDED } \\
\text { GROWTH ALL } \\
\text { AROUND }\end{array}$ & $\underbrace{}_{\substack{\text { SMALL CIRCLE } \\
\text { OF YESSELS } \\
\text { ONLY }}}$ & \\
\hline $\begin{array}{l}\text { MAJOR } \\
\text { VESSEL } \\
\text { PATTERN } \\
\text { B }\end{array}$ & $\begin{array}{l}3 \text { PAIRS OF } \\
\text { VESSELS, } \\
\text { DELICATE } \\
\text { PAITERN }\end{array}$ & $\begin{array}{l}4 \text { TO } 7 \text { PAIRS OF } \\
\text { DELICATE } \\
\text { POSTERIOR } \\
\text { VESSES WITHOUT } \\
\text { PERIPHERAL } \\
\text { "BRUSH BORDER" }\end{array}$ & \begin{tabular}{|l|} 
PILED ON \\
VESSELS \\
PERIPHERALLY \\
(BRUSHALA \\
BORDER)
\end{tabular} & $\begin{array}{l}\text { UNIFORM } \\
\text { PILED ON } \\
\text { VESSESE; BASIC } \\
\text { PATTERN SAILL } \\
\text { PAISCRNABLEL }\end{array}$ & $\begin{array}{l}\text { HEAVILY PILED } \\
\text { ON VESSELS; } \\
\text { NO BASIC } 3 \\
\text { PAIRS VISIBLE }\end{array}$ \\
\hline $\begin{array}{l}\text { PERI- } \\
\text { ARTERIOLAR } \\
\text { CAPILLARY } \\
\text { FREE ZONE. } \\
\text { C }\end{array}$ & $\begin{array}{l}\text { ZONE } \\
\text { APARENT } \\
\text { AROND EACH } \\
\text { ARTERIOLE TO } \\
\text { THE PERIPHERY }\end{array}$ & $\begin{array}{l}\text { PATCHY LOSS } \\
\text { OF CLEAR ZONE }\end{array}$ & \begin{tabular}{|l|} 
UNIFORM LOSS \\
OF CLEAR \\
ZONE
\end{tabular} & & \\
\hline $\begin{array}{l}\text { CAPILLARY } \\
\text { TUFT } \\
\text { FORMATION } \\
\quad D\end{array}$ & NONE & $\begin{array}{l}1 \text { OR } 2 \text { LARGE } \\
\text { OR SMALLAT } \\
\text { HHE PEEI A A PERY }\end{array}$ & \begin{tabular}{|l|} 
MORE THAN 3 \\
SCATTERED \\
NEAR THE \\
PERIPHERY
\end{tabular} & $\begin{array}{l}\text { SMALL OR LARGE } \\
\text { EXIENDING } \\
\text { TORARD THE } \\
\text { OISK }\end{array}$ & $\begin{array}{l}\text { EXTENSIVE } \\
\text { TUFT FORMATION } \\
\text { WITH A MASX OF } \\
\text { VESSELS OVER } \\
\text { YHE DISK }\end{array}$ \\
\hline
\end{tabular}

Fig. 2. Retinal scoring system. Total score for retina is equal to sum of scores in each of four categories. Reprinted with permission from Pediatrics, Vol. 73, p. 3, (C) 1984 (ref. 16).

Table 1. Experimental retinopathy (mean $\pm S E M)$

\begin{tabular}{lccccc}
\hline \multicolumn{5}{c}{ Scores (heparin treatment $v s$ saline } \\
treatment) & \\
\cline { 2 - 5 } & Vessel & Vessel & Capillary & Vitreal & \\
& growth & pattern & free zone & vessels & Total \\
\hline Heparin & $1.1 \pm 0.4$ & $1.8 \pm 0.7$ & $1.0 \pm 0.3$ & $2.1 \pm 1.1$ & $5.9 \pm 2.2$ \\
Saline & $1.2 \pm 0.4$ & $2.1 \pm 0.5$ & $1.1 \pm 0.3$ & $2.6 \pm 0.7$ & $7.1 \pm 1.7$ \\
$p$ & $\mathrm{NS}$ & $\mathrm{NS}$ & $\mathrm{NS}$ & $\mathrm{NS}$ & $\mathrm{NS}$ \\
\hline
\end{tabular}

on a clinical survey of actual heparin use in sick infants under 1 $\mathrm{kg}$ birth wt. On average, these infants received $0.5 \mathrm{U}$ of heparin per $\mathrm{mL}$ of hyperalimentation fluids in addition to fluids in other lines and periodic flushes. At an average of $150 \mathrm{~mL} / \mathrm{kg} / \mathrm{d}$, they received approximately $75 \mathrm{U} / \mathrm{kg} / \mathrm{d}$. The dose was doubled in the kitten model, but not increased further because of concerns for hemorrhage.

At $28 \mathrm{~d}$, kittens were killed, the retinal vasculature perfused with warmed Higgins india ink (Faber-Castell, Lewisburg, TN) diluted $50 \%$ in saline via aortic cannulation, and retinal flat mounts prepared (28). The retinas were coded and scored independently in a masked fashion by three individuals. Four components of the retinopathy were scored separately yielding a total
Table 2. Mean total retinopathy scores for heparin- and salinetreated kittens in each litter

\begin{tabular}{rccc}
\hline Litter & Heparin & Saline & Sign \\
\hline 1 & 8.75 & 3.40 & + \\
2 & 4.51 & 7.87 & - \\
3 & & 11 & - \\
4 & 6.13 & 7.17 & - \\
5 & 2.58 & 6.75 & - \\
6 & 4.13 & 7.87 & + \\
7 & 8.25 & 7.18 & - \\
8 & 3.33 & 5.35 & - \\
9 & 4.06 & 7.75 & + \\
10 & 7.33 & 6.25 & + \\
11 & 10.20 & 6.67 & - \\
12 & 7.79 & & + \\
13 & 6.91 & 7.61 & - \\
14 & 6.38 & 5.63 & - \\
15 & 6.38 & 6 & $6 / 15$ \\
16 & 3.69 & 7.94 & $p>0.25$ sign test \\
17 & 4.38 & 9.06 & \\
& & & \\
\hline
\end{tabular}

score of 13 for the worst cases and $0-1$ for normal retinal vascularization (16). The score categories (Fig. 2) included $A$ ), vessel growth or extent of vascularization in the retina (score 0 $3) ; B$ ), the major vessel pattern including number of vessels and patterns of vessel growth (score $0-4) ; C$ ), the periarteriolar capillary free zone (score $0-2$ ); and $D$ ), the amount of extraretinal neovascularization, specifically vitreal vessels (score 0-4). A binocular dissecting microscope (Bausch \& Lomb, Inc., Rochester, $\mathrm{NY}$ ) at $0.7-3 \mathrm{X}$ was used to score the retinas. The final score for each kitten was taken as the arithmetic mean of the scores from the left and right eyes across all three sets of scores. There were two final scores for each litter, the average of the saline-treated kitten scores and the average of the heparin-treated kitten scores.

The sample size was based on previous experience with this model where the total retinopathy score after a room-air recovery to 4 wk after $65 \mathrm{~h}$ of $80 \%$ oxygen at d 3 has been $5.3 \pm 2.5$ $($ mean \pm SD). Seventeen litters permit the detection of at least a 2 -point change in the total score, within litters, at an $\alpha$-error of 0.05 with a power of $80 \%$. This protocol was reviewed and approved by the University of Rochester, Committee on Animal Research.

\section{RESULTS}

All 17 litters completed the study and appeared healthy. Each group (saline and heparin) grew equally well (no statistically significant differences in their wt at birth and weekly intervals to $4 \mathrm{wk}$ ), and no hemorrhagic complications arose.

There were no statistically significant differences in either the total retinopathy score or any of the four subcategory scores when the heparin group was compared with the saline group by $t$ test on the aggregate scores, or the paired $t$ test on the differences between control and heparin groups within litters. Table 1 shows the retinopathy scores for each of the four subcategories and the total scores. Table 2 shows the mean total retinopathy score values by litter and analysis using the sign test on the direction of differences within each litter, which also confirms the paired $t$ test analysis $(p>0.25)$.

\section{DISCUSSION}

The degree of retinopathy in kittens treated with saline (control group) was consistent with observations in other studies $(16,28-$ 30 ). Heparin did not affect the OIR in the kitten in the selected dose, $150 \mathrm{U} / \mathrm{kg} / \mathrm{d}$ given s.c. 
Previous investigators have indicated that FGF are involved in eye development and vision. They have been shown to bind basement membranes of the eye, specifically the inner limiting membrane of the retina (31). Basement membranes play an important role in eye morphogenesis (32), and it has been speculated that their developmental modification could be involved in regulating their affinity for FGF (31). Further, in vitro experiments have shown that the basement membrane composition can be modified by treatment with FGF $(33,34)$. It has therefore been postulated that the FGF and extracellular matrix of the eye are involved jointly in proliferation of endothelial cells and differentiation in normal and pathologic states in the eye (33).

Several factors could be responsible for the lack of observed effect of heparin on OIR. Although in vitro experiments have shown that heparin potentiates the activity of aFGF in cultured cells (22-25) and in human endothelial cell proliferation (35), perhaps the in vivo model of OIR involves an aFGF effect that is already maximal and cannot be further potentiated. Alternatively, OIR might be driven by bFGF or other growth factors rather than aFGF. A third possibility may be that endogenous cell surface heparin is already sufficient to maximize the effect of aFGF. Conversely, the dose of heparin used may not have been high enough, although this dose was twice that in common clinical use. Finally, the s.c. route may not have presented the heparin to the tissues affected in a sufficiently high dose to have an effect. Premature infants are given heparin without established studies of its safety, but based on extrapolation downward between age and size from older children. Because the smallest survivors are so immature at birth now (36), we must heighten our awareness of the physiologic differences in the still-differentiating premature infant and his older counterpart. Despite this caution, these data do not support a basis for changing the current use of heparin in neonatal intensive care units.

In summary, we found no difference in the degree of retinopathy in the OIR kitten model when kittens were treated with heparin versus saline (control). This finding suggests that heparin administration to premature infants is not a significant factor in the incidence or severity of ROP.

Acknowledgment. The authors thank David Churchill and Derek Van Alstyne for their dedicated work on this project.

\section{REFERENCES}

1. Terry TL 1942 Extreme prematurity and fibroblastic overgrowth of persistent vascular sheath behind each crystalline lens. Am J Ophthalmol 25:203-204

2. Campbell K 1951 Intensive oxygen therapy as a possible cause of retrolenta fibroplasia: a clinical approach. Med J Aust 2:48-50

3. Patz A, Hoeck LE, DelaCruz E 1953 Studies on the effect of high oxygen administration in retrolental fibroplasia. Am J Ophthalmol 35:1248-1253

4. Lanman JT, Guy LP, Dancis J 1954 Retrolental fibroplasia and oxygen therapy. JAMA 155:223-226

5. Kinsey VE 1956 Retrolental fibroplasia: cooperative study of retrolental fibroplasia and the use of oxygen. Arch Ophthalmol 56:481-543

6. Guy LP, Lanman JT, Dancis J 1956 The possibility of total elimination of retrolental fibroplasia by oxygen restriction. Pediatrics 17:247-249

7. Ashton N, Ward B, Serpell G 1954 Effects of oxygen on developing retinal vessels with particular reference to the problem of retrolental fibroplasia. $\mathrm{Br}$ J Ophthalmol 38:397-433

8. Patz A, Eastham A, Higginbotham DH, Kleh T 1953 Oxygen studies in retrolental fibroplasia. II. The production of the microscopic changes of retrolental fibroplasia in experimental animals. Am J Ophthalmol 35:15111522

9. Kinsey VE, Arnold HJ, Kalina RE, Stern L, Stahlman M, Odell G, Driscoll JM, Elliott JH, Payne J, Patz A $1977 \mathrm{PaO}_{2}$ levels and retrolental fibroplasia: a report of the cooperative study. Pediatrics 60:655-668

10. Flynn JT, Bancalari E, Bawol R, Goldberg R, Cassady J, Schiffman J, Feuer W, Roberts J, Gillings D, Sim E, Buckley E, Bachynski BN 1987 Retinopathy of prematurity. A randomized prospective trial of transcutaneous oxygen monitoring. Ophthalmology 94:630-638

11. Gunn TR, Easdown J, Outerbridge EW, Aranda JV 1980 Risk factors in retrolental fibroplasia. Pediatrics 65:1096-1100

12. Shahinian L, Malachowski N 1978 Retrolental fibroplasia: a new analysis of risk factors based on recent cases. Arch Ophthalmol 96:70-74

13. Johnson RV, Donn SM 1988 Life span of intravenous cannulas in a neonatal intensive care unit. Am J Dis Child 142:968-971

14. Prost M 1988 Experimental studies on the pathogenesis of retinopathy of prematurity. Br J Ophthalmol 72:363-367

15. Baird A, Esch F, Gospodarowicz D, Guillemin R 1987 Retina- and eye-derived endothelial cell growth factors: partial molecular characterization and identity with acidic and basic fibroblast growth factors. Biochemistry 24:78557860

16. Phelps DL, Rosenbaum A 1984 Effects of marginal hypoxemia on recovery from oxygen-induced retinopathy in the kitten model. Pediatrics 73:1-6

17. Patz A 1980 Studies on retinal neovascularization. Invest Ophthalmol Vis Sci 1133-1138

18. D'Amore PA, Thompson RW 1987 Mechanisms of angiogenesis. Ann Rev Physiol 49:453-464

19. Folkman J, Klagsbrun M 1987 Angiogenic factors. Science 235:442-447

20. Maciag T, Mehlman T, Friesel R 1984 Heparin binds endothelial cell growth factor, the principal endothelial cell mitogen in bovine brain. Science 225:932-935

21. Wagner JA, D'Amore PA 1986 Neurite outgrowth induced by an endothelial cell mitogen isolated from retina. J Cell Biol 103:1363-1367

22. Walicke P, Cowan WM, Ueno N, Baird A, Guillemin R 1986 Fibroblast growth factor promotes survival of dissociated hippocampal neurons and enhances neurite extension. Proc Natl Acad Sci USA 83:3012-3016

23. Lipton SA, Wagner JA, Madison RD, D'Amore PA 1988 Acidic fibroblast growth factor enhances regeneration of processes by postnatal mammalian retinal ganglion cells in culture. Proc Natl Acad Sci USA 85:2388-2392

24. Schreiber AB, Kenney J, Kowalski WJ, Friesel R, Mehlman T, Maciag T 1985 Interaction of endothelial cell growth factor with heparin: characterization by receptor and antibody recognition. Proc Natl Acad Sci 82:6138-6142

25. Lobb RR, Harper JW, Fett JW 1986 Purification of heparin binding growth factors. Anal Biochem 154:1-14

26. Sudhalter J, Folkman J, Svahn C, Bergendal K, D'Amore P 1989 Importance of size, sulfation and anticoagulant activity in the potentiation of acidic fibroblast growth factor by heparin. J Biol Chem 264:6892-6897

27. Alessandri G, Raju K, Gullino PM 1984 Angiogenesis in vivo and selective mobilization of capillary endothelium in vitro by heparin-copper complex. Microcirc Endothelium Lymphatics 1:329-346

28. Phelps DL, Rosenbaum AL 1979 The role of tocopherol in oxygen-induced retinopathy: kitten model. Pediatrics 59(suppl):998-1005

29. Phelps DL, Rosenbaum A 1987 Effects of variable oxygenation and gradual withdrawal of oxygen during the recovery phase in oxygen-induced retinopathy: kitten model. Pediatr Res 22:297-301

30. Phelps DL 1988 Reduced severity of oxygen-induced retinopathy in kittens recovered in $28 \%$ oxygen. Pediatr Res 24:106-109

31. Jeanny JC, Fayein N, Moenner M, Chevallier B, Barritault D, Courtois Y 1987 Specific fixation of bovine brain and retinal acidic and basic fibroblast growth factors to mouse embryonic eye basement membranes. Exp Cell Res 171:63-75

32. Sugrue SP, Hay ED 1986 The identification of extracellular matrix (ECM) binding sites on the basal surface of embryonic corneal epithelium and the effect of ECM binding on epithelial collagen production. J Cell Biol 102:1907-1916

33. Moczar E, Tassin J, Courtois Y 1983 Interaction of bovine epithelial lens (BEL) cells with extracellular matrix (ECM) and eye derived growth factor (EDGF). Exp Cell Res 149:95-104

34. Robinson J, Gospodarowicz D 1983 Glycosaminoglycans synthesized by cultured bovine corneal endothelial cells. J Cell Physiol 117:368-376

35. Thornton SC, Mueller SN, Levine EM 1983 Human endothelial cells: use of heparin in cloning and long-term serial cultivation. Science 222:623-625

36. Valentine PH, Jackson JC, Kalina RE, Woodrum DE 1989 Increased survival of low birth weight infants: impact on the incidence of retinopathy of prematurity. Pediatrics $84: 442-445$ 